\title{
Review Article \\ The Relationship between Traditional Chinese Medicine and Modern Medicine
}

\author{
Jingcheng Dong ${ }^{1,2}$ \\ ${ }^{1}$ Institute of Integrated Medicine, Huashan Hospital, Fudan University, Shanghai 200040, China \\ ${ }^{2}$ Department of Integrated Medicine, Huashan Hospital, Fudan University, Shanghai 200040, China
}

Correspondence should be addressed to Jingcheng Dong; jcdong2004@126.com

Received 2 January 2013; Revised 27 April 2013; Accepted 17 June 2013

Academic Editor: Christopher G. Lis

Copyright (C) 2013 Jingcheng Dong. This is an open access article distributed under the Creative Commons Attribution License, which permits unrestricted use, distribution, and reproduction in any medium, provided the original work is properly cited.

\begin{abstract}
The essence of the traditional Chinese medicine has always been the most advanced and experienced therapeutic approach in the world. It has knowledge that can impact the direction of future modern medical development; still, it is easy to find simple knowledge with mark of times and special cultures. The basic structure of traditional Chinese medicine is composed of three parts: one consistent with modern medicine, one involuntarily beyond modern medicine, and one that needs to be further evaluated. The part that is consistent with modern medicine includes consensus on several theories and concepts of traditional Chinese medicine, and usage of several treatments and prescriptions of traditional Chinese medicine including commonly used Chinese herbs. The part that is involuntarily beyond modern medicine contains several advanced theories and important concepts of traditional Chinese medicine, relatively advanced treatments, formula and modern prescriptions, leading herbs, acupuncture treatment and acupuncture anesthesia of traditional Chinese medicine that affect modern medicine and incorporates massage treatment that has been gradually acknowledged by modern therapy. The part that needs to be further evaluated consists not only the knowledge of pulse diagnosis, prescription, and herbs, but also many other aspects of traditional Chinese medicine.
\end{abstract}

\section{Introduction}

The essence of traditional Chinese medicine has always been the most advanced and experienced medicine in the world. Its vast system is full of practical medical technology and proven experiences that have been gradually incorporated into modern medicine; it has knowledge that can impact the direction of future medical development, yet its knowledge is simple enough to fit changing times and varied cultures. The basic structure of traditional Chinese medicine is composed of the following three parts: the part that is consistent with modern medicine, the part that is involuntarily beyond modern medicine, and the part that needs to be further evaluated or abandoned.

\section{The Part That Is Consistent with Modern Medicine}

In the 16th century, what is now known as "western medicine" was introduced to China but was not commonly used and thus had little effect. It was not until the Opium War that "western medicine" began to develop in China. Therefore, prior to that event, traditional Chinese medicine was always the leading force of medical care in China.

The key to successful medicine lies in its efficacy. A popular Chinese saying states "Excellence is from experience." The foundation of traditional Chinese medicine is based on 5,000 years of practice and experiences. With the founding of a new China in 1949, western medicine in the region also began to play a large role in medical care. As modern (westernized) medicine's impact increased, it led to the development of "integrative medicine" at the end of the 1950s. Theories, therapeutic principles, technologies, and understanding of the life sciences were elaborated, and the basic structure of traditional Chinese medicine also became clearer. Most importantly, traditional Chinese medicine began to reach a common point with modern medicine.

2.1. Consensus on Several Theories and Conceptions of Traditional Chinese Medicine. For example, "the essence of 
kidney" is a core concept of traditional Chinese medical theory. Studies by Shen showed that "kidney deficiency syndrome" is equivalent to the aging in modern medicine, regardless of its external performance and internal changes [1-3]. Studies by Chen et al. showed that what is known as "heart qi deficiency" is associated with cardiac insufficiency in modern medicine [4-6].

2.2. Consensus on Inspection, Auscultation-Olfaction, Inquiry, and Palpation Method. There are four main components of traditional Chinese medicine diagnosis $[7,8]$. Inspection is a method to determine the medical status by visually examining the changes in appearance and the movement of the whole body or part of the body. Generally speaking, inspection includes examination of the tongue as well as the observation of a patient's external appearance, in order to recognize the internal and external manifestations of disease. Visual examination is consistent with modern medicine's emphasis on observation of a patient appearance and movement. For example, a pale lip can indicate anemia in modern medicine.

The use of auscultation-olfaction, including listening to the sounds and smelling for odors, is also consistent with modern medicine. If a patient speaks loudly and powerfully, the physician can determine that the patient is full of energy. Conversely, if a patient's voice is weak or he does not want to talk, it is most likely that the patient's diseases are caused by “deficiency." A patient's bodily odors can also reveal much about the respective illness. If a patient has a rotten apple like odor, it is likely diabetic ketoacidosis. Inquiry refers to the gathering of a thorough history and reviewing the systems. These include physical and mental feelings, life history, family history, past medical history, onset time, and the present symptoms, which are widely used both in traditional medicine and modern medicine.

2.3. Consensus on Several Treatments of Traditional Chinese Medicine. Therapeutic studies show that Chinese medicine and modern medicine have reached a consensus on the methods of diaphoresis, purging, vomiting, warming, clearing, neutralizing, eliminating, and reinforcing (eight commonly used treatments in traditional Chinese medicine). For instance, the "reinforcing method" is able to improve neuroendocrine regulatory function, enhance the body's ability to combat stress, adjust immune function, and improve the body's systemic function. Diaphoresis is able to promote perspiration and defervescence as well as play a role in reducing inflammation among other methods adopted by modern medicine.

2.4. Consensus on Several Prescriptions of Traditional Chinese Medicine and Commonly Used Chinese Herbs. Illnesses cured by many ancient Chinese compounds are similar to certain diseases or conditions also seen in modern medicine and are summarized in Table 1.

There are many Chinese herbs either given as single drugs or as formulations that have been effective treatments for particular illnesses for thousands of years. With the development of modern medicine, the pharmacology and mechanism of action of many of these Chinese herbs have been determined, so that traditional Chinese medicine has gradually formed a consensus with modern medicine (Table 2).

\section{The Part Ahead of Modern Medicine Involuntarily}

Traditional Chinese medicine is a practical medicine built on experience. The theoretical system is built by means of an ancient plain materialist philosophy, the method of "syndrome differentiation," and the use of natural means to treat illness rather than emphasizing consistency with contemporary science and technology $[9,10]$. Unlike modern medicine that has view that "Nature that cannot be certified cannot be conquered," keeping abreast of requirements of contemporary science, traditional Chinese medicine with the overall old and simple features involuntarily gives awareness beyond the era. The so-called "integrative medicine" is able to reveal this essence continually.

3.1. Several Advanced Theories and Important Conceptions of Traditional Chinese Medicine. In terms of medical theories and ways of thinking, traditional Chinese medicine has a significant contribution to modern medicine. For example, the theory of the "correspondence between man and universe" in traditional Chinese medicine is the unified outlook of body and environment. What are known as the "biological life" theory and the "biological clock" theory in modern medicine refers to the patterns of hormone secretion, and treating diseases according to the place of origin are all the embodiment of "correspondence between man and universe." The views of "unity of opposites" and "balance amongst dynamic forces" indicate the existence of universal laws in human life. Although these views are emphasized in modern life science, both approaches differ from traditional Chinese medicine because traditional Chinese medicine always considers these views as its guiding ideology and as fundamental law. Therefore, the cognitive degrees of Chinese medicine and western medicine in these views are of difference.

For example, studies by Shen show that "kidney deficiency" is due to neuroendocrine disturbance and preaging of the function of the hypothalamic-pituitary axis, which is consistent with the hypothesis that "the senile bell lies in hypothalamus" proposed by Everiff in the 1980s [11]. However, the practice of traditional Chinese medicine precedes modern medicine by thousands of years. Our study found that the knowledge of "chronic disease involving kidney" in traditional Chinese medicine has a profound connotation in modern life sciences. Many diseases, such as airway inflammatory diseases, with long-term recurrence, often exacerbate the pathological changes in the anti-inflammatory system and HPA axis. Patients suffering from these are known to have significant "kidney deficiency." We summarized many theories and concepts with advanced knowledge in traditional Chinese medicine in Table 3.

3.2. Several Relatively Advanced Treatments of Traditional Chinese Medicine. "Same treatment for different diseases," 
TABLE 1: Several ancient herbal formulas that form consensus with modern medicine.

\begin{tabular}{|c|c|c|c|c|c|}
\hline Formula & Origin & Composition & Function & Traditional application & $\begin{array}{l}\text { Modern } \\
\text { application }\end{array}$ \\
\hline $\begin{array}{l}\text { Ginseng } \\
\text { Decoction } \\
{[30]}\end{array}$ & $\begin{array}{l}\text { Shiyao } \\
\text { Shenshu from } \\
\text { Xiuyueruban- } \\
\text { jing } \\
\text { Houlu }\end{array}$ & Large ginseng 20-30 g & $\begin{array}{l}\text { Invigorating qi } \\
\text { to prevent } \\
\text { prostration }\end{array}$ & $\begin{array}{l}\text { It is seen after hemorrhage, ulcer, and sore. } \\
\text { Those who get qi and blood deficiency, pale } \\
\text { complexion, aversion to cold with fever, cold } \\
\text { limbs, spontaneous sweating or cold } \\
\text { sweating, and faint pulse catch this kind of } \\
\text { disease. }\end{array}$ & $\begin{array}{l}\text { Hemorrhagic or } \\
\text { cardiogenic } \\
\text { shock }\end{array}$ \\
\hline $\begin{array}{l}\text { Sini } \\
\text { Decoction } \\
{[16,31]}\end{array}$ & $\begin{array}{l}\text { Taiyang } \\
\text { meridian } \\
\text { syndrome } \\
\text { from Treatise } \\
\text { on Febrile } \\
\text { Diseases }\end{array}$ & $\begin{array}{l}\text { Radix Glycyrrhizae } \\
\text { Preparate (monarch, } \\
\text { two liang), Rhizoma } \\
\text { Zingiberis (minister, } \\
\text { one and half liang), } \\
\text { Radix Aconiti } \\
\text { Preparata (assistant, } \\
\text { one piece, uncooked) }\end{array}$ & $\begin{array}{l}\text { Warming the } \\
\text { middle } \\
\text { energizer to } \\
\text { dispel cold, } \\
\text { Rescuing from } \\
\text { collapse by } \\
\text { restoring Yang }\end{array}$ & $\begin{array}{l}\text { Shanghan Taiyang disease which is } \\
\text { mistakenly treated by sweating method } \\
\text { damages yang, yangming, taiyin, shaoyin, } \\
\text { jueyin and cholera, displaying such } \\
\text { symptom as deadly cold hand and foot, } \\
\text { aversion to cold, vomiting and no eagerness } \\
\text { to drink, hypogastralgia and diarrhea, } \\
\text { spiritual deficiency and always sleeping, } \\
\text { white and slippery tongue coating, faint } \\
\text { pulse, and such diseases as plague, malaria, } \\
\text { Jue disease, Collapse disease and pain } \\
\text { disease. All above belong to yin syndrome. }\end{array}$ & Multiple shocks \\
\hline $\begin{array}{l}\text { Zhenwu } \\
\text { Decoction } \\
{[15]}\end{array}$ & $\begin{array}{l}\text { Shaoyin } \\
\text { meridian } \\
\text { syndrome } \\
\text { from Treatise } \\
\text { on Febrile } \\
\text { Diseases }\end{array}$ & $\begin{array}{l}\text { Poria cocos, Paeonia } \\
\text { Lactiflora Pall, Ginger } \\
\text { (sliced) each three } \\
\text { liang, Atractylodes } \\
\text { macrocephala koidz } \\
\text { (two liang), Radix } \\
\text { Aconiti Lateralis } \\
\text { Preparata (one piece, } \\
\text { processed) }\end{array}$ & $\begin{array}{l}\text { Warming yang } \\
\text { to promote } \\
\text { diuresis }\end{array}$ & $\begin{array}{l}\text { It directs to deficiency of spleen-yang and } \\
\text { kidney-yang and Water and Dampness } \\
\text { Retention. The syndromes show as follows: } \\
\text { dysuria; heavy limbs with pain; } \\
\text { hypogastralgia and diarrhea; limb swelling; } \\
\text { white tongue coating and no eagerness to } \\
\text { drink; deep pulse; taiyang-diseases which } \\
\text { are overused sweating method; edema due } \\
\text { to yang insufficiency; sweating but not } \\
\text { relieve the symptom; fever; epigastric throb; } \\
\text { dizziness; trembling body. }\end{array}$ & $\begin{array}{l}\text { Cardiogenic or } \\
\text { renal edema }\end{array}$ \\
\hline $\begin{array}{l}\text { Yupingfeng } \\
\text { Powder [17] }\end{array}$ & $\begin{array}{l}\text { Spontaneous } \\
\text { Sweating } \\
\text { Decoction } \\
\text { from Danxi's } \\
\text { experiential } \\
\text { therapy }\end{array}$ & $\begin{array}{l}\text { Saposhnikovia } \\
\text { divaricata, Radix } \\
\text { astragali, one liang } \\
\text { each, Atractylodes } \\
\text { macrocephala koidz } \\
\text { (two liang) Three } \\
\text { qian. The above with } \\
\text { one and half cup of } \\
\text { water and three pieces } \\
\text { of ginger }\end{array}$ & $\begin{array}{l}\text { Tonifying } \\
\text { Spleen and } \\
\text { supplementing } \\
\text { defending qi; } \\
\text { Consolidating } \\
\text { exterior for } \\
\text { arresting } \\
\text { sweating }\end{array}$ & $\begin{array}{l}\text { It is called by TCM immunomodulator. It } \\
\text { treats spontaneous sweating due to } \\
\text { deficiency of yang, susceptibility of } \\
\text { pathogenic wind; body injury by wind, rain, } \\
\text { cold and dampness, and withered skin; } \\
\text { sweating and disgusting wind; pale } \\
\text { complexion, pale tongue, and thin-white } \\
\text { coating, floating and deficient pulse. It also } \\
\text { treats deficient people with loosened striae } \\
\text { and susceptibility of pathogenic wind. }\end{array}$ & $\begin{array}{l}\text { Rising the } \\
\text { immune } \\
\text { function }\end{array}$ \\
\hline
\end{tabular}

one of the most important and characteristic concepts in traditional Chinese medicine reflects the spirit of "syndrome differentiation and treatment" and refers to the thought that different diseases at certain stages of development show the same pathogenesis. And therefore, the same therapeutic principles can be applied to diseases. For example, according to modern medical diagnosis, different diseases are able to be cured by "reinforcing kidney and replenishing qi" as long as they are attributed to "kidney-qi deficiency" syndrome. Modern research has shown that this concept of "same treatment for different diseases" is likely to be one of the directions of modern medicine in the future. Because some of the "walls" that exist between the diseases are not always reasonable, the reason for division is often based on anatomy, rather than etiological and pathological changes. Studies have shown that different diseases with similar syndrome often have common pathological and physiological changes. It is easier to achieve better effects by using the same prescription because different diseases may have comparable changes at the cellular, molecular, and genetic levels, and drug targets or the target groups may be similar across various diseases.

\subsection{Several Relatively Advanced Formula and Modern Prescriptions}

3.3.1. Realgar-Indigo Naturalis Formula. Acute promyelocytic leukemia (APL) has a poor prognosis. In the 1980s, a famous Chinese medical expert in China, Doctor Shi-lin Huang, designed a Realgar-Indigo naturalis formula (RIF), in which, realgar, a mined ore, is the principal element and Indigo naturalis, Salvia miltiorrhiza, and Radix psudostellariae are adjuvant components to assist the effects of realgar. The main components of RIF are realgar, Indigo naturalis, 
TABLE 2: Consensus of several commonly used herbs.

\begin{tabular}{|c|c|c|c|c|c|}
\hline Herb & Efficacy & $\begin{array}{l}\text { Traditional } \\
\text { application }\end{array}$ & Essential component & Pharmacologic action & $\begin{array}{l}\text { Modern } \\
\text { application }\end{array}$ \\
\hline Ephedra [32] & $\begin{array}{l}\text { Antiperspiration, } \\
\text { relieves lung } \\
\text { congestion, } \\
\text { antiasthmatic, } \\
\text { diuretic }\end{array}$ & $\begin{array}{l}\text { Used for respiratory } \\
\text { infections caused by } \\
\text { "wind," asthmatic } \\
\text { cough and chest } \\
\text { distress, edema } \\
\text { caused by wind, } \\
\text { asthma, pruritis }\end{array}$ & Pseudoephedrine & $\begin{array}{l}\text { Ephedrine induces } \\
\text { central nervous system } \\
\text { excitation; improves } \\
\text { myocardial } \\
\text { contractility, increases } \\
\text { cardiac output; acts on } \\
\text { adreno-receptor; } \\
\text { significantly relaxes } \\
\text { bronchial smooth } \\
\text { muscle. } \\
\text { Pseudoephedrine has } \\
\text { better effects on } \\
\text { dieresis compared with } \\
\text { ephedrine; minimal } \\
\text { erethitic effects on } \\
\text { vascular system. }\end{array}$ & $\begin{array}{l}\text { Mainly used for } \\
\text { bronchial } \\
\text { asthma, the } \\
\text { common cold, } \\
\text { allergic } \\
\text { response, nasal } \\
\text { congestion, } \\
\text { edema, } \\
\text { hypotension }\end{array}$ \\
\hline $\begin{array}{l}\text { Datura flower } \\
\text { [33] }\end{array}$ & $\begin{array}{l}\text { Suppresses cough } \\
\text { and relieves } \\
\text { dyspnea; anesthetic } \\
\text { and odynolytic; } \\
\text { relieves spasms } \\
\text { and pain }\end{array}$ & $\begin{array}{l}\text { Used for cough, } \\
\text { asthma, abdominal } \\
\text { pain; rheumatic } \\
\text { aches, epilepsy, } \\
\text { infantile convulsion, } \\
\text { and anesthesia. }\end{array}$ & $\prod_{\substack{\mathrm{O} \\
\text { Cytospaz }}}^{\overline{\mathrm{O}}}$ & $\begin{array}{l}\text { Analogous to an } \\
\text { alpha-blocking agent, } \\
\text { scopomamine has } \\
\text { analgesic functions and } \\
\text { can strengthen the } \\
\text { analgesic action of } \\
\text { sauteralgyl via blocking } \\
\text { adrenergic receptors; } \\
\text { reduces vagal } \\
\text { inhibitory effects on } \\
\text { the heart and } \\
\text { stimulates the } \\
\text { apneustic center. }\end{array}$ & $\begin{array}{l}\text { For gastric and } \\
\text { duodenal ulcers } \\
\text { and gall bladder } \\
\text { disease, kidney } \\
\text { disease, } \\
\text { intestinal } \\
\text { cramps, and can } \\
\text { also be used for } \\
\text { tremor palsy. }\end{array}$ \\
\hline
\end{tabular}

For hotness and humidity, vomiting, dysentery jaundice, fever, coma, upset, Coptis [34] $\begin{aligned} & \text { Heat dampness, } \\ & \text { fire detoxification }\end{aligned}$ insomnia, hematemesis, and epistaxis due to blood hot, toothache, carbuncles.<smiles>COc1ccc2cc3[n+](cc2c1OC)CCc1cc2c(cc1-3)OCO2</smiles>

Berberine
Antipathogenic microbe; antiarrhythmic, antihypertensive, positive inotropic effect; detoxification, anti-inflammatory, antipyretic, and antiplatelet aggregation.
Commonly used to treat bacterial gastroenteritis, dysentery, and other gastrointestinal diseases.
For excessive yin rejecting yang, loss of

Reviving yang for resuscitation, supplementing fire and strengthening

Aconite [35] yang, eliminating cold to stop pain. The most effective drug for recovering depleted yang. yang due to severe diaphoresis, vomiting and diarrhea, cold extremities, cold hypochondrium due to insufficiency of yang, dorsal furuncle and pyocutaneous disease, and other unretractable cold diseases. protrusion. Coryza

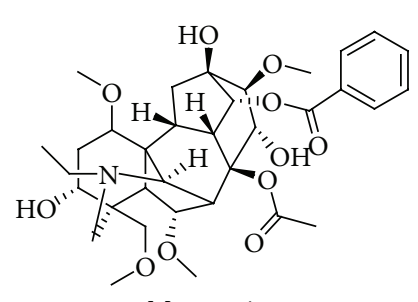

Myoctonine
Has a cardiotonic effect, dilates blood vessels, increases blood flow, improves blood circulation, antiarrhythmic, anticold, improves tolerance to hypoxia tolerance and anti-inflammatory and analgesic effects.
Clinically used to alleviate pain, especially suitable for the digestive system and cancer pain. 
TABLE 2: Continued.

\begin{tabular}{|c|c|c|c|c|c|}
\hline Herb & Efficacy & $\begin{array}{l}\text { Traditional } \\
\text { application }\end{array}$ & Essential component & Pharmacologic action & $\begin{array}{l}\text { Modern } \\
\text { application }\end{array}$ \\
\hline $\begin{array}{l}\text { Honeysuckle } \\
{[36]}\end{array}$ & $\begin{array}{l}\text { Heat clearing and } \\
\text { detoxicating, } \\
\text { detumescence, } \\
\text { improves eyesight, } \\
\text { dispels wind and } \\
\text { heat }\end{array}$ & $\begin{array}{l}\text { For anthracia and } \\
\text { furunculosis, } \\
\text { pharyngitis, } \\
\text { hieropyra, } \\
\text { hematochezia caused } \\
\text { by pyretic toxicity, } \\
\text { anemopyretic cold, } \\
\text { fever caused by warm } \\
\text { pathogen }\end{array}$ & The main component is volatile & $\begin{array}{l}\text { Antimicrobial; } \\
\text { anti-inflammatory and } \\
\text { antipyretic effects, } \\
\text { strengthens the } \\
\text { immune function, } \\
\text { centra analepsia effects, } \\
\text { lipid-lowering effect, } \\
\text { antiendotoxin. }\end{array}$ & $\begin{array}{l}\text { For gastric and } \\
\text { duodenal ulcers } \\
\text { and gall bladder } \\
\text { disease, kidney } \\
\text { disease, } \\
\text { intestinal } \\
\text { cramps, and can } \\
\text { also be used for } \\
\text { tremor palsy. }\end{array}$ \\
\hline
\end{tabular}

TABLE 3: Advances in traditional Chinese medicine that are ahead of modern medicine.

\begin{tabular}{ll}
\hline $\begin{array}{l}\text { Traditional Chinese medicine } \\
\text { thousands of years ago) }\end{array}$ & $\begin{array}{l}\text { Modern medicine } \\
\text { (recent decades) }\end{array}$ \\
\hline $\begin{array}{l}\text { The integration of life } \\
\text { knowledge/experience with } \\
\text { traditional Chinese medicine }\end{array}$ & $\begin{array}{l}\text { Ranging from primary studies } \\
\text { of a single gene or protein to } \\
\text { current use of genomics, } \\
\text { proteomics and informatics }\end{array}$ \\
\hline $\begin{array}{l}\text { Emotional pathopoiesis and its } \\
\text { correspondence between man } \\
\text { and his environment }\end{array}$ & $\begin{array}{l}\text { Gradual recognition of } \\
\text { psychological factors and its } \\
\text { relationship with physiology } \\
\text { and pathology. }\end{array}$ \\
\hline $\begin{array}{l}\text { Syndrome differentiation, } \\
\text { abidance by the triple } \\
\text { pathogens and physique theory }\end{array}$ & $\begin{array}{l}\text { Establishment of individual } \\
\text { treatment }\end{array}$ \\
\hline $\begin{array}{l}\text { Chinese compound } \\
\text { (multitarget herbal treatment) }\end{array}$ & $\begin{array}{l}\text { From primary single target } \\
\text { drugs to multitarget drugs, } \\
\text { significantly reduce the side } \\
\text { effects of medical treatment. }\end{array}$ \\
\hline
\end{tabular}

and Salvia miltiorrhiza, with tetraarsenic tetrasulfide (A), indirubin (I), and tanshinone IIA (T) as major active ingredients, respectively [12-14]. Multicenter clinical trials showed that a complete remission rate of $96.7 \%$ [15] to $98 \%$ [16] and a 5 -year overall survival rate of $86.88 \%$ [17] were achieved in APL patients receiving RIF, with moderate adverse effects such as gastrointestinal discomfort and rash. Doctor Zhu Chen clarified the molecular mechanism of the compound Huangdai tablets in the treatment of APL in 2008 from the perspective of molecular biology and biochemistry in the renowned journal Proceedings of the National Academy of Sciences of the United States of America (PNAS). The results show that As4S4 induces degradation of the cancer protein, thus reversing the increase in cancer cells and making them differentiate and mature. Tanshinone and indirubin promote the ubiquitination of the oncoprotein and accelerate its degradation, further promoting the differentiation and maturation of the leukemia cells and inhibiting cell cycle and proliferation of cancer cells. Animal studies also showed that the use of natural indigo after realgar substantially reduced toxicity. These reflect the concepts of typical "minister" (the place inferior to "monarch" drug) and "assistant" (the place inferior to "minister" drug) effect. Tanshinone and indirubin increase the production of channel proteins that deliver As4S4, which significantly increase the concentration of As4S4 in leukemia cells, improving its efficacy. Both tanshinone and indirubin play the role of "guide" (the place inferior to "assistant" drug). The compound Huangdai has a synergistic effect with the other components greater than its three individual components by the joint application of each component (Figure 1).

3.3.2. Airway Stabilizer Solution. The airway stabilizer solution created by Doctor Jing-cheng Dong is based on Xiao Qing Long Tang (Little Dragon Decoction) and Ding Chuan Tang (Anti-asthmatic Decoction), composed of ligusticum wallichii, ginkgo biloba, skullcap, Asarum, ginger, almonds, earthworm, rehmannia, and magnolia. It is effective in the clinical treatment of bronchial asthma and variability of cough. The various components and the basis for its efficacy are rooted in traditional Chinese medical theory, and the composition of the drug may be the main material basis for its efficacy (Table 4).

3.4. Several Leading Herbs. The study of Chinese medicine is driven in part by the development of modern pharmacology. For instance, Artemisia annua was recorded in the "Handbook of Prescriptions for Emergency" (written by Hong Ge in Eastern Jin Dynasty) as a drug used to treat malaria. Modern research has shown that it has an antimalarial active ingredient (the peroxide group of sesquiterpene lactone) consisting of only 3 elements, carbon, hydrogen, and oxygen. It is a completely different novel compound compared to known antimalarial drug structures. This finding overturned the judgment of experts who insisted that the structure of the antimalarial drugs must have a nitrogen-containing heterocyclic ring $[18,19]$. It helps provide a direction for the design and synthesis of new drugs. In addition, ginseng, skullcap, astragalus, epimedium, and other herbs were also each shown to have a unique effect (Table 5).

\subsection{Acupuncture Treatment and Acupuncture Anesthesia That} Affect Modern Medicine. Those who practice acupuncture approach the treatment by looking at pathology in the whole body. According to different body conditions, varied 


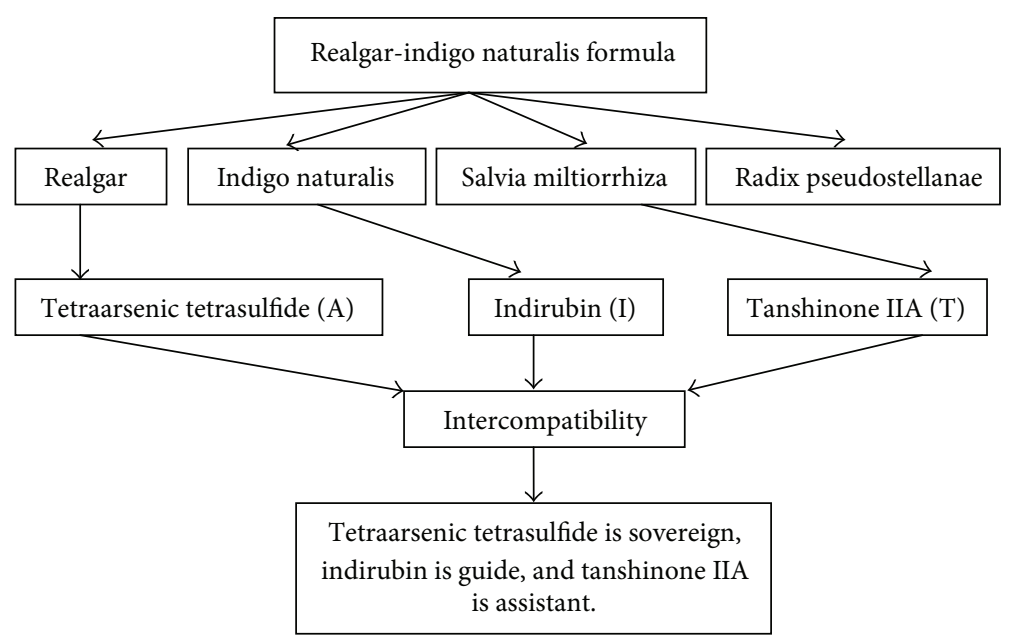

FIGURE 1: Realgar-Indigo naturalis formula.

TABLE 4: Components and ingredients of the airway stabilizer solution.

\begin{tabular}{lll}
\hline Name & Herb & Ingredient \\
\hline & Ephedra & $\begin{array}{l}\text { Ephedrine and other minor } \\
\text { components }\end{array}$ \\
& Ligusticum wallichii & Tetramethylpyrazine \\
& Ginkgo biloba & Ginkgolide \\
Airway & Scutellaria & Baicalin \\
solution & Asarum & Racemic go A black alkali \\
& Ginger ale & Ginger oil glycosides \\
& Almonds & Amygdalin \\
& Earthworm & Earthworms antipyretic \\
& Rehmannia & Habitat catalpol \\
& Magnolia & Volatile oil \\
\hline
\end{tabular}

acupoints and manipulations are selected. The selection influences multiple targets and many diseases and stimulates the body to treat diseases, affecting the pathological process and improving physique.

This adjustment is accomplished by the integration of the central nervous system, including cortex recombination, neural plasticity, and release of various neurotransmitters and hormones $[20,21]$. The basis of acupuncture may be in changes in gene expression.

Acupuncture anesthesia is a method used to prevent surgical pain and relieve physiological dysfunction. It is suitable for those who are allergic to narcotic drugs. Since 1958, Shanghai No. 1 People's Hospital used it instead of narcotic drugs to perform tonsillectomies. Since then, acupuncture anesthesia has been passed from general usage to selected application. According to its clinical effect and scientific evaluation, acupuncture anesthesia is effectively used in thyroid surgery, surgery of posterior cranial fossa, craniocerebral operation, anterior cervical surgery, pulmonary resection, caesarean section, tubal ligation, and tooth extraction. It is also used in some surgeries with uncertain results like hysterectomy, caldwell-luc operation, subtotal gastrectomy, and strabismus surgery. It has not proved to provide effective anesthesia in limb surgery and perineal surgery.

The basis of acupuncture anesthesia is the adjustment to inhibit large pain pathways by the negative reflection of spinal pain [22-24]. The acupuncture signal and the pain signal from the pain region transmit impulses into the brain. Acupuncture stimulates the antipain material to reduce the pain. Endogenous opioids participate in this process due to the increased release of opioids. Several neurotransmitters are related to acupuncture anesthesia, and some relatively central cerebral nuclei were found. CCK-8 has the negative-reflection-to-opioid effect, which is the vital factor of acupuncture and morphine. The effect of electric acupuncture depends on the balance of central opioid and CCK-8. The acupuncture signals can be reflected on some regional area of the brain to deal with the injury stimulations, which might be the physical basis of acupuncture anesthesia. Different frequencies of electric acupuncture differentiate the pain-relieving effects, which may be related to the specific expression of central genes. Two $\mathrm{Hz}$ electric acupuncture is widely used in the brain treatment, while $100 \mathrm{~Hz}$ has a narrow extension in the brain treatment. Psychological factors are not the deciding factors for success, but they are also quite important.

3.6. Massage Treatment That Is Gradually Acknowledged by Modern Medicines. Massage treatment utilizes the particular skills with hands or limbs to practice manipulation on the surface of the body. Therefore, it has the direct effect of activating blood and dispersing stagnation, smoothing tendons, and improving malformation. On the other hand, massage reflectively influences the neuro and body fluid by acupoint-meridian-viscera network. Clinical researches show that appropriate manipulations can result in improvement of outcomes [25].

Modern research studies show that massage can promote blood and lymph circulation, increase metabolism, and assist the repair of soft tissue injury [26]. The diastolic function 
TABLE 5: Several advanced commonly used herbs.

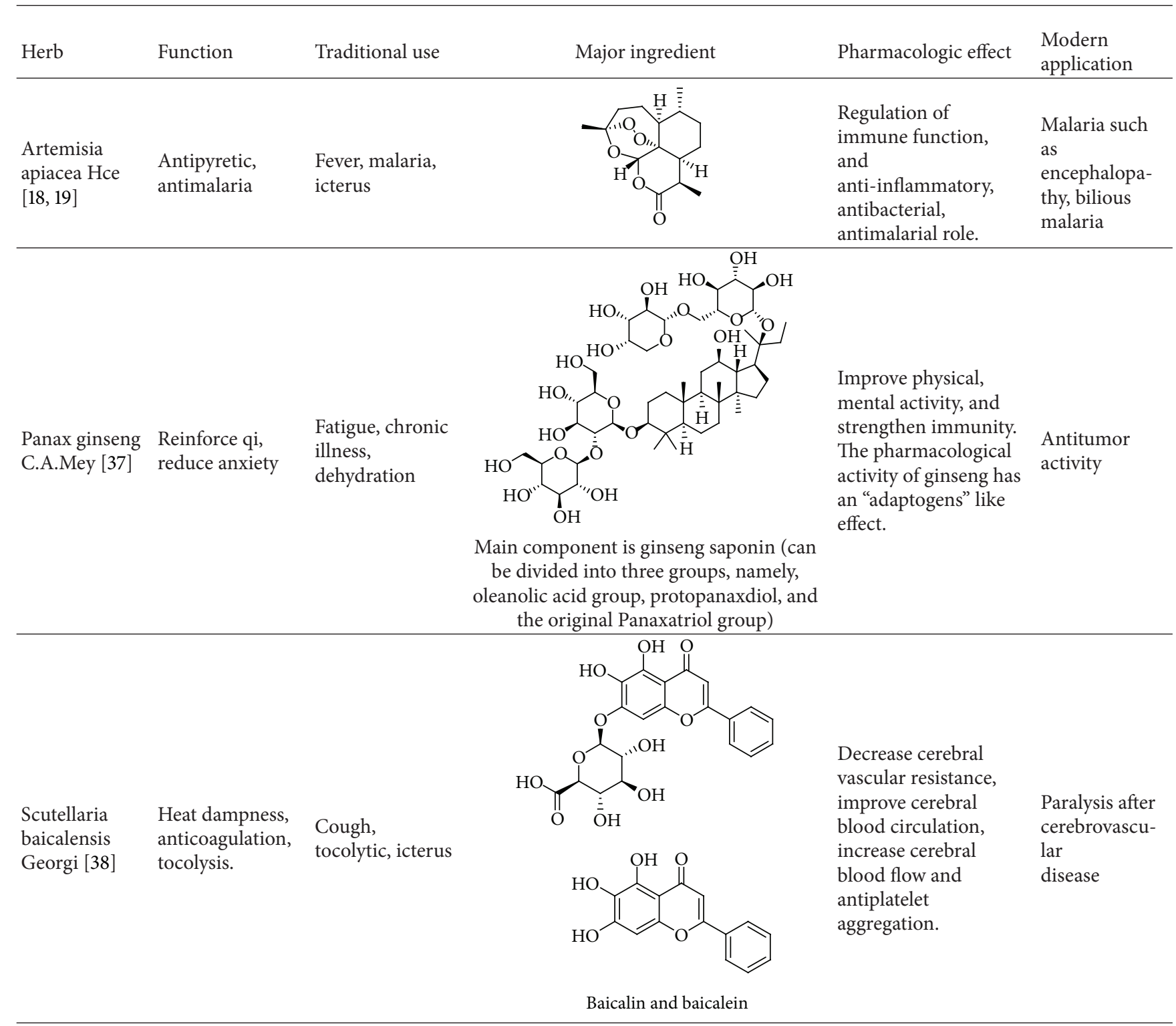

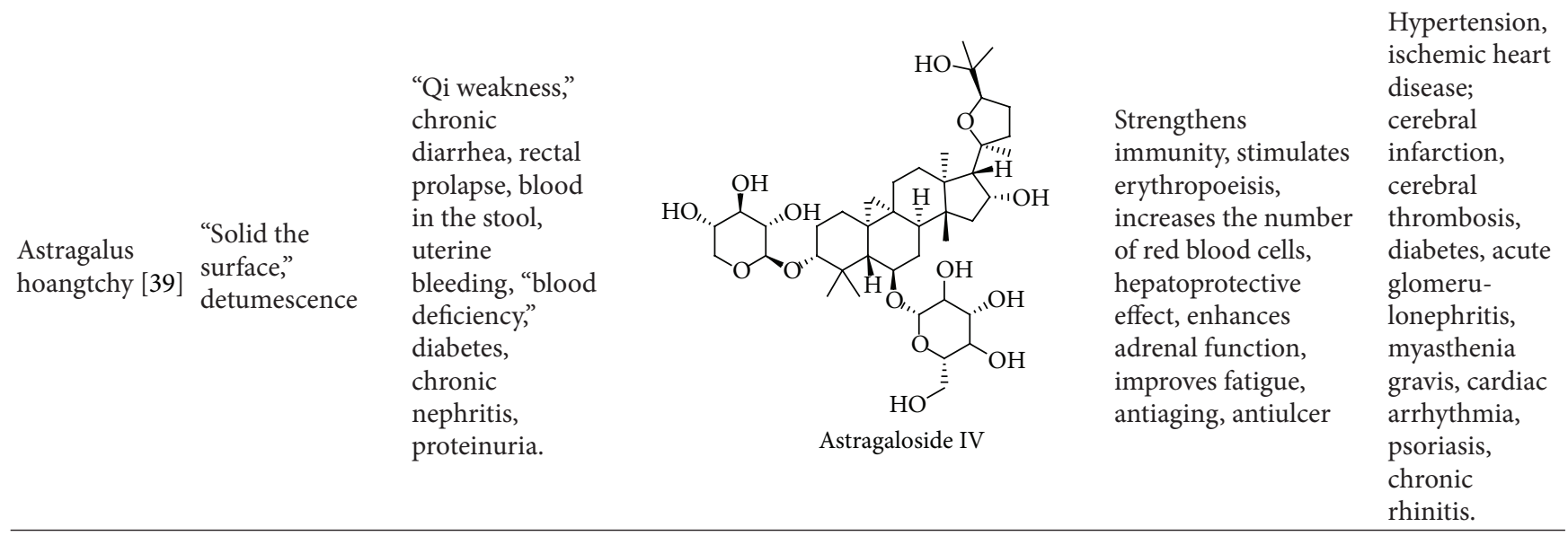


TABLE 5: Continued.

\begin{tabular}{|c|c|c|c|c|c|}
\hline Herb & Function & Traditional use & Major ingredient & Pharmacologic effect & $\begin{array}{l}\text { Modern } \\
\text { application }\end{array}$ \\
\hline $\begin{array}{l}\text { Herba } \\
\text { epimedii [40] }\end{array}$ & $\begin{array}{l}\text { Reinforce } \\
\text { kidney yang, } \\
\text { antirheumatism }\end{array}$ & $\begin{array}{l}\text { Atrophic } \\
\text { arthritis, } \\
\text { dormientum } \\
\text { spermatorrhea, } \\
\text { hypertension. }\end{array}$ & Icariin & $\begin{array}{l}\text { Modulates the } \\
\text { hypothalamic- } \\
\text { pituitary-gonadal axis } \\
\text { and adrenal cortical } \\
\text { axis, and the thymus } \\
\text { axis, } \\
\text { immunomodulatory } \\
\text { effects, antiasthmatic, } \\
\text { anti-inflammatory } \\
\text { and antiviral effects, } \\
\text { improves the } \\
\text { hemodynamic and } \\
\text { hemorheology. }\end{array}$ & $\begin{array}{l}\text { Polio; } \\
\text { neurasthenia; } \\
\text { treatment of } \\
\text { chronic } \\
\text { bronchitis; } \\
\text { male } \\
\text { hormone-like } \\
\text { effects. }\end{array}$ \\
\hline
\end{tabular}

of the heart improves, and arteriole function improves as well after massage. The total cell count increases, while lung function improves. The content of catecholamines in plasma decreases so that the autonomic nervous system is inhibited, which can cause a reduction in pain [27]. Massage can effectively increase digestion in the stomach, adjust the secretion of stomach fluid, and release the spasm of smooth muscle [28]. When ST36 and BL23 are manipulated, the function of periphery blood T lymphocyte elevates. Rubbing manipulation, embrocation, and kneading manipulation could increase the elasticity and glossiness of skin.

In short, skilled massage manipulation can effectively prevent diseases by the combination of static strength and motive force in a localized point or throughout the entire body.

\section{Some Parts That Need to Be Newly Recognized or Abandoned}

In the system of human science, including medical science, concepts change from new to old, and ideas become theories and facts. All the concepts and rules indicate the stability. However, this kind of stability is conditional, partial, and relative, while instability is absolute and unconditional. Any scientific systems should confess their demerits and rectify them so as to generate new concepts, methods, and theory. Meanwhile, the initial phase of modern medicine and traditional Chinese medicine were founded in specific cultures and eras. So TCM theory should be divided into two parts, one of which needs to be promoted, the other of which need to be abandoned. Integrative medicine is an important way to achieve this [29].

4.1. About Palpation. "Cunkou pulse" should be newly recognized. It belongs to the "Lung Meridian of Hand-Taiyin." "Classic of Questioning" (written by Qui Bian in the Warring StatesPeriod) put forward that "Cunkou pulse" can detect diseases of the whole body. "Lung" controls whole meridians, is the master of "qi", and is the origin of "qi" and "blood."
Therefore, it can reflect all the changes of viscera, meridians and "qi-blood" to diagnose diseases. "The Internal Canon of Medicine" (written in Huang in the Warring States period) pointed out that meridians include meridians and collaterals, not vessels. The pulse we palpate originates from the heart, which beats. The meridian cannot beat, so it should not be able to be palpated. The pulse is only one kind of syndrome. Not all diseases can be presented by the pulse. Therefore, palpation is part of signs, but one should be careful when palpation is the only examination method.

4.2. About Formula Prescription. Although formulary prescriptions are beneficial in medicine, they still have some demerits. It is hard to distinguish the "assistant" and the "guide" in some prescriptions, and therefore, it is necessary to conduct further research. "Compendium of Materia Medica" (written by Si-miao Sun in the Ming Dynasty) has lots of prescription to treat sterility. If a sterile female drank a cup of rain water in the spring, she would become fertile. If a sterile female stole a lamp from a rich person's bed, she would also become fertile. Even broom, dishwater, ashes on widow's bed, the wood in toilet, the trees fired by thunder, and the rope hung by itself were thought to treat diseases.

4.3. About Chinese Medicine. Si-miao Sun (a well-known doctor in Chinese history) recorded saltpeter as bitter and hot in taste, extremely cold, and nontoxic. Modern researchers find saltpeter contains nitrocompound which may cause liver cancer. Also Pollia was recorded as bitter and hot in taste, warm and nontoxic, although it contains aristolochic acid which may cause kidney failure, lymphoma, kidney cancer, and liver cancer.

\section{Conclusion}

China is a nation composed of many ethnic groups, many with their own subcultures, beliefs, and history. Because of this, it is important to note that traditional Chinese medicine should have two concepts: firstly, it only refers to traditional 
medicine in the Han nationality; secondly, it is the sum of traditional medicines of all nationalities in the Chinese mainland. With respect to the structure and characteristic of traditional medicines, they can be divided into three parts: the knowledge and facts in agreement with modern medicine, the knowledge and practices not recognized in modern medicine that may be valuable in the future practice of modern medicine, and finally, the component of traditional medicine that has been adequately disproven and should be abandoned from future medical practice.

\section{Acknowledgments}

This project was funded from the grants from the National Basic Science Program of China (2009CB523001) and National Natural Science Program of China (no. 81173390/H2902).

\section{References}

[1] Z. Y. Shen, "Contemplation and practice on research from kidney essence to syndrome essence-promotion of mutual supplement of Chinese and Western medicines to a higher level by research on integration of Chinese and Western medicines," Shanghai Journal of Traditional Chinese Medicine, vol. 34, no. 4, pp. $4-7,2000$.

[2] Z. Shen, Z. Zheng, and W. Guo, "Clinical and experimental study on retardation of immunosenescence by kidney tonifying principle," Chinese Journal of Integrated Traditional and Western Medicine, vol. 22, no. 3, pp. 178-181, 2002.

[3] Z. Shen, "Study on the regulation of HPAT axis molecular network in patients with aging-physiologic shen-deficiency syndrome," Chinese Journal of Integrated Traditional and Western Medicine, vol. 24, no. 9, pp. 841-843, 2004.

[4] K. J. Chen, "Certain progress in the treatment of coronary heart disease with traditional medicinal plants in China," American Journal of Chinese Medicine, vol. 9, no. 3, pp. 193-196, 1981.

[5] K. J. Chen, "Efficacy of traditional medicine in cardiovascular diseases in the People's Republic of China," Ancient Science of Life, vol. 1, no. 4, pp. 192-199, 1982.

[6] K. J. Chen and J. Su, "Progress of research on ischemic stroke treated with Chinese medicine," Journal of Traditional Chinese Medicine, vol. 12, no. 3, pp. 204-210, 1992.

[7] J. Y. Dai, S. J. Sun, H. J. Cao et al., "Applications of new technologies and new methods in ZHENG differentiation," Evidence-Based Complementary and Alternative Medicine, vol. 2012, no. 5, Article ID 298014, 8 pages, 2012.

[8] Z. L. Chen, "Research on the "four methods of diagnosis" in traditional Chinese medicine and western medicine," Chinese Journal of Integrated Traditional and Western Medicine, vol. 4, no. 4, pp. 253-255, 1984.

[9] M. Jiang, C. Lu, C. Zhang et al., "Syndrome differentiation in modern research of traditional Chinese medicine," Journal of Ethnopharmacology, vol. 140, no. 3, pp. 634-642, 2012.

[10] W. Jiang, "Therapeutic wisdom in traditional Chinese medicine: a perspective from modern science," Trends in Pharmacological Sciences, vol. 26, no. 11, pp. 558-563, 2005.

[11] S. K. Chen, "Creation and analysis of new conception and theory of integrated medicine," Chinese Journal of Integrated Traditional and Western Medicine, vol. 11, no. 1, pp. 44-46, 1991.
[12] L. Wang, G. Zhou, P. Liu et al., "Dissection of mechanisms of Chinese medicinal formula Realgar-Indigo naturalis as an effective treatment for promyelocytic leukemia," Proceedings of the National Academy of Sciences of the United States of America, vol. 105, no. 12, pp. 4826-4831, 2008.

[13] X. Hu, F. Liu, and R. Ma, "Application and assessment of Chinese arsenic drugs in treating malignant hematopathy in China," Chinese Journal of Integrative Medicine, vol. 16, no. 4, pp. 368377, 2010.

[14] E. Q. Li, L. Xu, Z. Q. Zhang et al., "Retrospective analysis of 119 cases of pediatric acute promyelocytic leukemia: comparisons of four treatment regimes," Experimental and Therapeutic Medicine, vol. 4, no. 1, pp. 93-98.

[15] Z. H. Hou and Z. M. Hou, "Analysis of Zhenwu Decoction," Journal of Emergency in Traditional Chinese Medicineno, vol. 19, no. 3, pp. 487-487, 2012.

[16] G. Tan, W. Liao, X. Dong et al., "Metabonomic profiles delineate the effect of traditional Chinese medicine Sini decoction on myocardial infarction in rats," PLoS ONE, vol. 7, no. 4, Article ID e34157, 2012.

[17] J. Gao, J. Li, X. Shao et al., "Antiinflammatory and immunoregulatory effects of total glucosides of Yupingfeng powder," Chinese Medical Journal, vol. 122, no. 14, pp. 1636-1641, 2009.

[18] C. H. Blanke, G. B. Naisabha, M. B. Balema, G. M. Mbaruku, L. Heide, and M. S. Müller, "Herba Artemisiae annuae tea preparation compared to sulfadoxine- pyrimethamine in the treatment of uncomplicated falciparum malaria in adults: a randomized double-blind clinical trial," Tropical Doctor, vol. 38, no. 2, pp. 113-116, 2008.

[19] E. Hsu, "Chinese propriety medicines: an "alternative modernity?" The Case of the anti-malarial substance artemisinin in east Africa," Medical Anthropology, vol. 28, no. 2, pp. 111-140, 2009.

[20] G. A. Ulett, J. Han, and S. Han, "Traditional and evidencebased acupuncture: history, mechanisms, and present status," Southern Medical Journal, vol. 91, no. 12, pp. 1115-1120, 1998.

[21] T. J. Kaptchuk, "Acupuncture: theory, efficacy, and practice," Annals of Internal Medicine, vol. 136, no. 5, pp. 374-383, 2002.

[22] J. S. Han and L. Terenius, "Neurochemical basis of acupuncture analgesia," Annual Review of Pharmacology and Toxicology, vol. 22, pp. 193-220, 1982.

[23] L. H. Lianfang He, "Involvement of endogenous opioid peptides in acupuncture analgesia," Pain, vol. 31, no. 1, pp. 99-121, 1987.

[24] Z. Zhao, "Neural mechanism underlying acupuncture analgesia," Progress in Neurobiology, vol. 85, no. 4, pp. 355-375, 2008.

[25] D. Kalauokalani, D. C. Cherkin, K. J. Sherman, T. D. Koepsell, and R. A. Deyo, "Lessons from a trial of acupuncture and massage for low back pain: patient expectations and treatment effects," Spine, vol. 26, no. 13, pp. 1418-1424, 2001.

[26] T. M. Field, "Massage therapy effects," American Psychologist, vol. 53, no. 12, pp. 1270-1281, 1998.

[27] T. Field, M. Hernandez-Reif, M. Diego, S. Schanberg, and C. Kuhn, "Cortisol decreases and serotonin and dopamine increase following massage therapy," International Journal of Neuroscience, vol. 115, no. 10, pp. 1397-1413, 2005.

[28] M. A. Diego, T. Field, and M. Hernandez-Reif, "Vagal activity, gastric motility, and weight gain in massaged preterm neonates," Journal of Pediatrics, vol. 147, no. 1, pp. 50-55, 2005.

[29] L. Rees and A. Weil, "Integrated medicine: imbues orthodox medicine with the values of complementary medicine," British Medical Journal, vol. 322, no. 7279, pp. 119-120, 2001. 
[30] C. J. Song, “ten effective remedies' and Ginseng Decoction," Ginseng Research, vol. 17, no. 2, pp. 2-3, 2005.

[31] J. P. Chen, B. Y. Tan, K. W. Wu, M. S. Zhang, L. J. Li, and C. Han, "Compatibility Law of monkshood and liquorice in Sini Decoction," Chinese Journal of Experimental Traditional Medical Formulare, vol. 7, no. 3, pp. 5-7, 2001.

[32] Y. Kasahara, H. Hikino, and S. Tsurufuji, "Antiinflammatory actions of ephedrines in acute inflammations," Planta Medica, vol. 51, no. 4, pp. 325-331, 1985.

[33] H. Kuang, B. Yang, Y. Xia, and W. Feng, "Chemical constituents from the flower of Datura metel L," Archives of Pharmacal Research, vol. 31, no. 9, pp. 1094-1097, 2008.

[34] J. Y. Cho, K. U. Baik, E. S. Yoo, K. Yoshikawa, and M. H. Park, "In vitro antiinflammatory effects of neolignan woorenosides from the rhizomes of Coptis japonica," Journal of Natural Products, vol. 63, no. 9, pp. 1205-1209, 2000.

[35] T. Kosuge and M. Yokota, "Studies on cardiac principle of aconite root," Chemical and Pharmaceutical Bulletin, vol. 24, no. 1, pp. 176-178, 1976.

[36] X. Jin, K. Ohgami, K. Shiratori et al., "Effects of blue honeysuckle (Lonicera caerulea L.) extract on lipopolysaccharideinduced inflammation in vitro and in vivo," Experimental Eye Research, vol. 82, no. 5, pp. 860-867, 2006.

[37] A. S. Attele, J. A. Wu, and C. Yuan, "Ginseng pharmacology: multiple constituents and multiple actions," Biochemical Pharmacology, vol. 58, no. 11, pp. 1685-1693, 1999.

[38] Z. Gao, K. Huang, X. Yang, and H. Xu, "Free radical scavenging and antioxidant activities of flavonoids extracted from the radix of Scutellaria baicalensis Georgi," Biochimica et Biophysica Acta, vol. 1472, no. 3, pp. 643-650, 1999.

[39] B. Shao, W. Xu, H. Dai, P. Tu, Z. Li, and X. Gao, "A study on the immune receptors for polysaccharides from the roots of Astragalus membranaceus, a Chinese medicinal herb," Biochemical and Biophysical Research Communications, vol. 320, no. 4, pp. 1103-1111, 2004.

[40] F. Xie, C. Wu, W. Lai et al., "The osteoprotective effect of Herba epimedii (HEP) extract in vivo and in vitro," Evidence-Based Complementary and Alternative Medicine, vol. 2, no. 3, pp. 353361, 2005. 


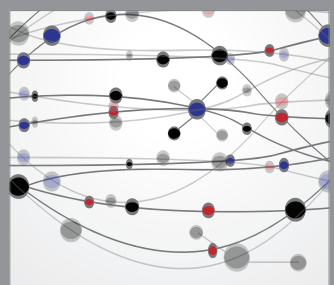

The Scientific World Journal
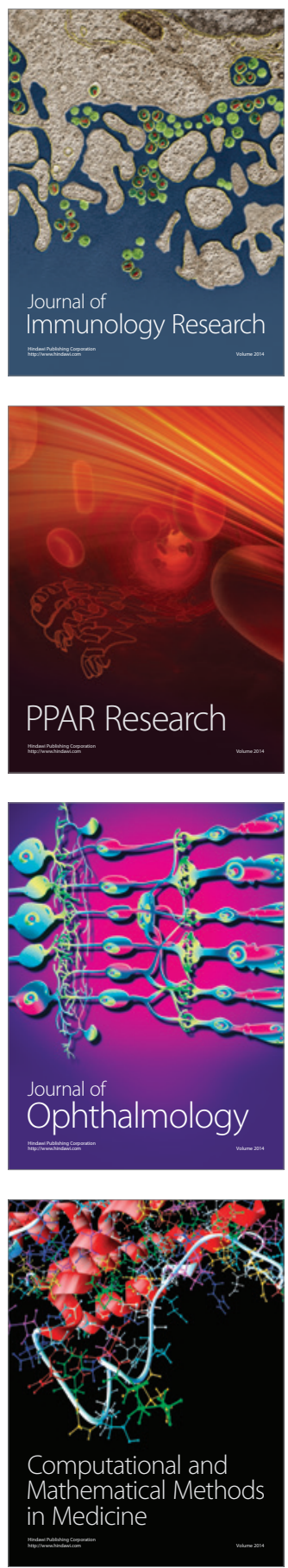

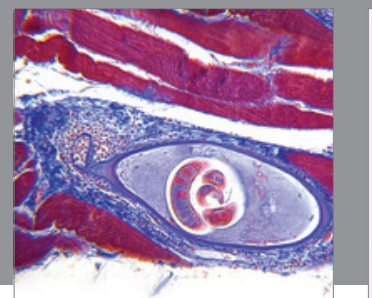

Gastroenterology

Research and Practice
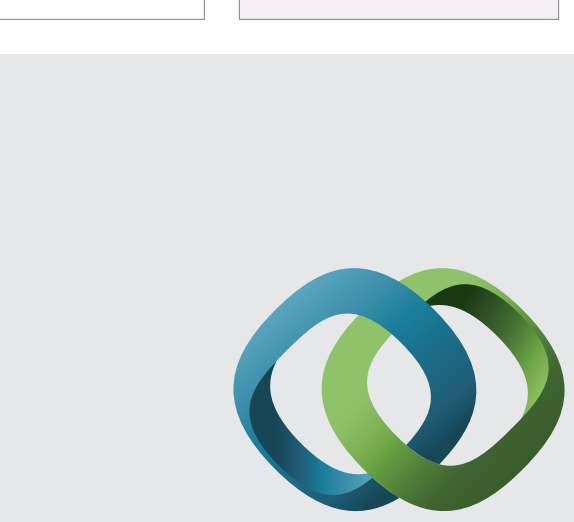

\section{Hindawi}

Submit your manuscripts at

http://www.hindawi.com
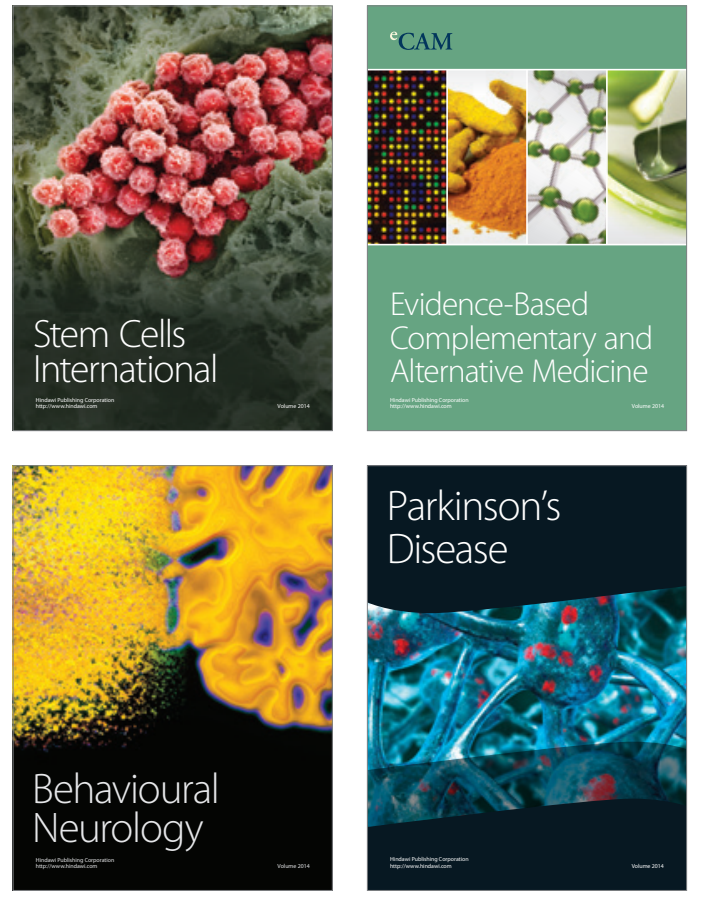
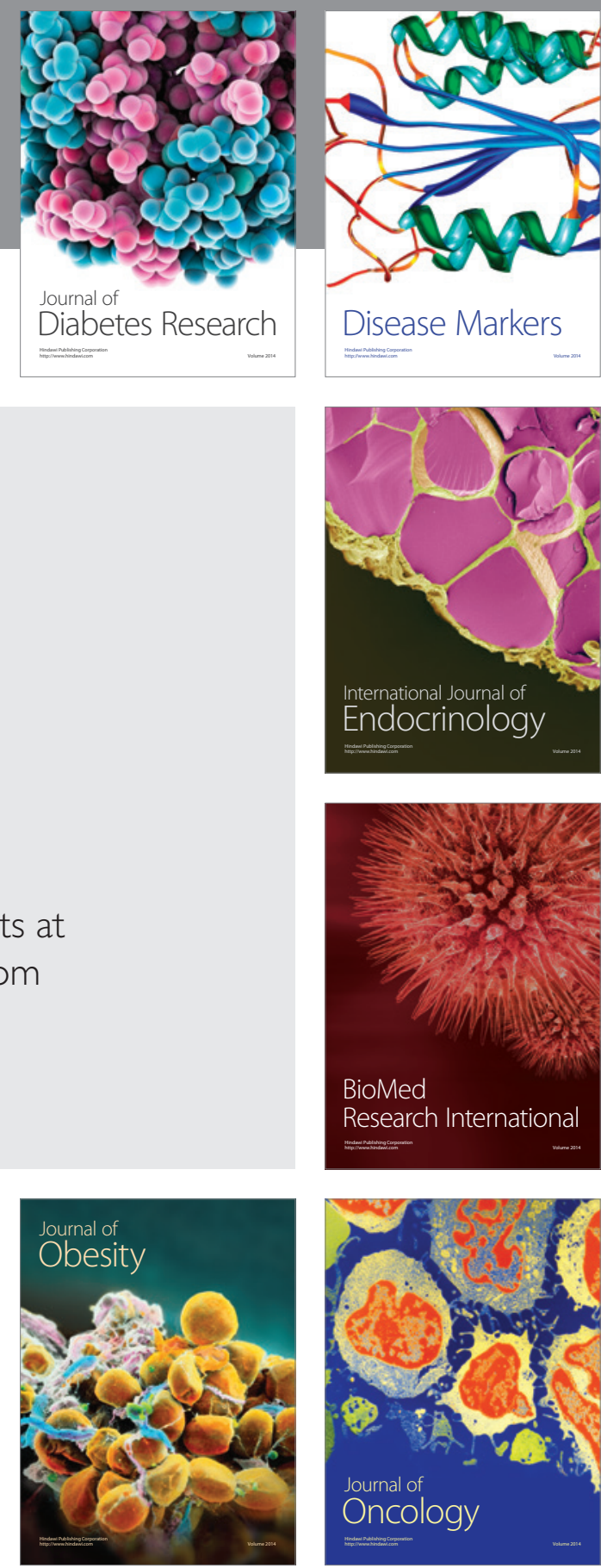

Disease Markers
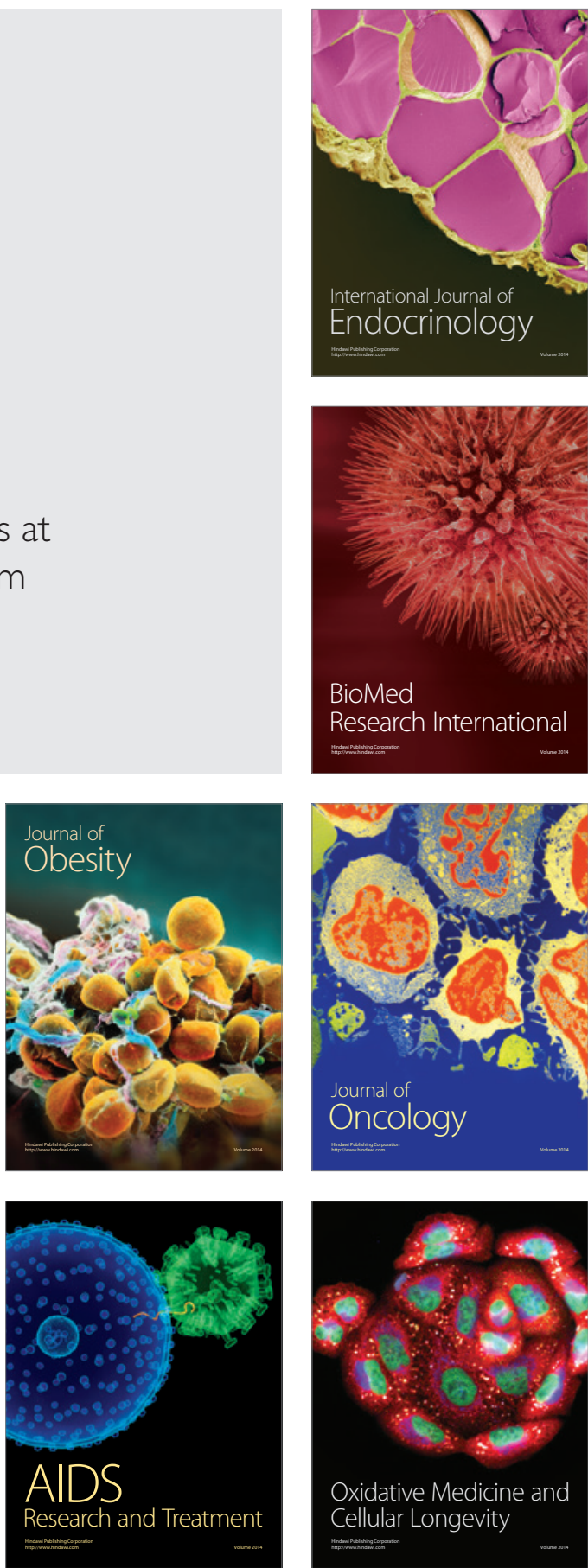